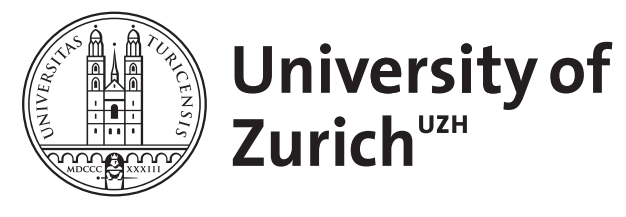

\title{
An Analysis of Shareholder Agreements
}

\author{
Chemla, Gilles ; Ljungqvist, Alexander ; Habib, Michel A
}

\begin{abstract}
Shareholder agreements govern the relations among shareholders in privately held firms, such as joint ventures and venture capital-backed companies. We provide an economic explanation for key clauses in such agreements 14namely, put and call options, tag-along and drag-along rights, demand and piggy-back rights, and catch-up clauses. In a dynamic moral hazard setting, we show that these clauses can ensure that the contract parties make efficient ex ante investments in the firm. They do so by constraining renegotiation. In the absence of the clauses, ex ante investment would be distorted by unconstrained renegotiation aimed at (i) precluding value-destroying ex post transfers, (ii) inducing value-increasing ex post investments, or (iii) precluding hold-out on value-increasing sales to a trade buyer or the IPO market.
\end{abstract}

DOI: https://doi.org/10.1162/JEEA.2007.5.1.93

Posted at the Zurich Open Repository and Archive, University of Zurich ZORA URL: https://doi.org/10.5167/uzh-63184

Journal Article

Published Version

Originally published at:

Chemla, Gilles; Ljungqvist, Alexander; Habib, Michel A (2007). An Analysis of Shareholder Agreements. Journal of the European Economic Association, 5(1):93-121.

DOI: https://doi.org/10.1162/JEEA.2007.5.1.93 


\title{
AN ANALYSIS OF SHAREHOLDER AGREEMENTS
}

\section{Gilles Chemla \\ Imperial College and DRM-CNRS}

\section{Michel A. Habib}

University of Zurich

\author{
Alexander Ljungqvist \\ New York University
}

\begin{abstract}
Shareholder agreements govern the relations among shareholders in privately held firms, such as joint ventures and venture capital-backed companies. We provide an economic explanation for key clauses in such agreements-namely, put and call options, tag-along and drag-along rights, demand and piggy-back rights, and catch-up clauses. In a dynamic moral hazard setting, we show that these clauses can ensure that the contract parties make efficient ex ante investments in the firm. They do so by constraining renegotiation. In the absence of the clauses, ex ante investment would be distorted by unconstrained renegotiation aimed at (i) precluding value-destroying ex post transfers, (ii) inducing value-increasing ex post investments, or (iii) precluding hold-out on value-increasing sales to a trade buyer or the IPO market. (JEL: G34)
\end{abstract}

\section{Introduction}

Shareholder agreements specify the rights and duties of shareholders when those prescribed by law and regulation are thought not to be appropriate.

Acknowledgments: We would like to thank Ekkehart Boehmer, Patrick Bolton (the Editor), Mike Burkart, Zsuzsanna Fluck, Paolo Fulghieri, David Goldreich, Sumantra Goshal, Denis Gromb, Dirk Hackbarth, Chris Hennessy, Peter Högfeldt, Josh Lerner, Gilad Livne, Jan Mahrt-Smith, Georg Nöldeke, Kjell Nyborg, Christine Parlour, Pim Piers, Ailsa Roell, Kristian Rydqvist, Klaus Schmidt, Dorothea Shäfer, Emily Sims, John Stopford, Per Strömberg, Ernst-Ludwig von Thadden, Raman Uppal, Andrew Winton, two anonymous referees, and seminar participants at the University of Arizona, NHH Bergen, the University of British Columbia, the University of California at Berkeley, Columbia Law School, the CEPR European Summer Symposium on Financial Markets in Gerzensee, HEC Lausanne, the AAA-SG Meetings at Humboldt University, the Western Finance Association Meetings in Vancouver, INSEAD, ISCTE, the London Business School, the first RICAFE Conference at the London School of Economics, McGill University, HEC Paris, the University of Porto, Princeton University, the Stockholm School of Economics, the DFG meetings at the University of Vienna, the University of Warwick, the University of Washington at Seattle, and the University of Zurich for helpful discussions. All errors are our own. Chemla gratefully acknowledges funding from SSHRC and the Bureau of Asset Management. Habib gratefully acknowledges funding from NCCRFINRISK and the URPP Finance and Financial Markets, and the hospitality of ESA Beyrouth and HEC Lausanne. All authors are also affiliated with the Centre for Economic Policy Research.

E-mail addresses: Chemla: g.chemla@imperial.ac.uk; Habib: habib@isb.unizh.ch; Ljungqvist: aljungqv@stern.nyu.edu 
Shareholder agreements are used mostly when at least some shareholders are actively involved in managing the company. Prominent examples include the shareholder agreements that govern joint ventures and venture capital-backed firms. ${ }^{1}$

Shareholder agreements generally grant the parties the following rights: the option to put their stakes to their partners or to call their partners' stakes, in part or in whole, at a strike price typically set at "fair" value; tag-along rights (or cosale agreements) which allow the parties to demand of a trade buyer buying their partners' stakes the same treatment as received by their partners; drag-along rights which allow the parties to force their partners to join them in selling their stakes to a trade buyer; demand rights (or registration rights) which allow the parties to force their partners to agree to taking the firm public in an IPO; piggyback rights which allow the parties to demand to be included in an IPO in proportion to their stakes in the firm; and catch-up clauses which maintain the parties' claims to part of the payoff from a trade sale or an IPO when the parties have ceded their stakes to their partners following the partners' exercise of a call option.

We provide an economic explanation for these clauses in a dynamic moral hazard setting. We view the clauses as serving to maintain the parties' shares of the payoff from the firm in situations where, after the initial investments have been made, the parties' ownership stakes in the firm must be altered in order to

(i) preclude a party from engaging in an ex post transfer at the other parties' expense;

(ii) induce value-increasing ex post investment in the firm; or

(iii) prevent a party from holding out on a value-increasing sale of the firm to a trade buyer or the IPO market.

In the absence of the relevant clauses, renegotiation, intended to achieve the necessary changes in the parties' stakes, may distort the parties' shares of the firm's payoff, thereby distorting their ex ante investments in the firm. By constraining renegotiation so as to maintain the parties' shares of the payoff, the clauses we discuss serve to maintain the parties' incentives to make the efficient ex ante investments.

We show that put options maintain the parties' shares of the payoff when the parties' stakes in the firm must be altered in order to preclude ex post transfers from the firm. Tag-along rights deny the parties the ability to increase their share of the payoff by threatening to sell their stake to a trade buyer who would decrease the value of the firm, or by preceding the other parties in selling their stake to

1. Standard shareholder agreements are described in Bernstein (1988), Freedman (1994), Martel (1991), and Stedman and Jones (1990). Joint venture contracts are described in Herzfeld and Wilson (1996), and Scott (1999); and venture capital contracts in Bartlett (1994) and Stedman and Jones (1990). Contracts appear to be strikingly similar across countries and legal systems (Martel 1991). See the Appendix for a brief description of the clauses most commonly found in shareholder agreements. 
a trade buyer who will increase the value of the firm. Drag-along rights deny the parties the ability to increase their share of the payoff by threatening to hold out on a value-increasing trade sale. Demand rights deny the parties the ability to increase their share of the payoff by threatening to veto a value-increasing IPO. Piggy-back rights deny the parties the ability to increase their share of the payoff by including a disproportionate fraction of their own shares in the IPO. Call options perform a similar role to put options when the problem of ex post transfers is replaced by that of ex post investment. Catch-up clauses deny the holders of a call option the ability to use the option to increase their share of the gains from a trade sale.

Each clause can be viewed as an option with a strike price determined endogenously after the valuation is realized. The option is explicit in the case of the put and call options, and implicit in the case of the remaining clauses. In particular, drag-along rights and catch-up clauses are forms of call options, whereby a party can call his partners' stakes. Tag-along rights, demand rights, and piggyback rights are forms of put options, whereby a party can put his stake to a trade buyer or to the public market. These (implicit) options are state-dependent, for their exercise is dependent on the appearance of a trade buyer or on the firm going public. State-dependence is important. It avoids the simultaneous exercise of conflicting options and confines the optionholder's ability to exploit the strong bargaining power conferred by the option to the state in which the option can be exercised. This contrasts with the state-independent bargaining power conferred by ownership.

Nöldeke and Schmidt $(1995,1998)$ consider the use of options to solve the hold-up problem. ${ }^{2}$ They show that a contract that grants a party the option to impose a specific trade at a fixed price can solve the hold-up problem. One possible view of our paper is as an application of Nöldeke and Schmidt's (1995) results to shareholder agreements. We do not disagree with such a view but note that there are important differences as well as close similarities between the work of Nöldeke and Schmidt and ours. To situate our work in relation to that of Nöldeke and Schmidt, we use a classification scheme introduced by Bolton and Dewatripont (2005, p. 563). Bolton and Dewatripont classify papers on the holdup problem along three dimensions. The first dimension is the extent to which the level of trade is contractible: can a contract be entered into ex ante, mandating a specific trade ex post, which one party can ask a court to enforce even in the face of opposition by the other party? The second dimension is the distribution of ex post bargaining power. The third dimension is the presence of externalities: whether, in the terminology of Che and Hausch (1999), the parties' investments

2. A hold-up problem arises when relationship-specific investment makes a party vulnerable to opportunism on the part of its partner. See Grossman and Hart (1986), Hart and Moore (1988, 1990), and Williamson (1985). 
are selfish or cooperative. A selfish investment benefits only the party making the investment, whereas a cooperative investment benefits both the party that has made the investment and the party that has not. An important result of Che and Hausch is that, with cooperative investments, contracts cannot solve the hold-up problem when the parties cannot commit not to renegotiate the contract. ${ }^{3}$

On the first dimension, we follow Nöldeke and Schmidt (1995) in assuming that a "specific performance" contract can be written. We thus differ from Hart and Moore (1988), for example, who assume only contracting-at-will-that is, that a contract mandating a specific trade ex post can only be enforced by a court if both parties agree to it. We note, however, that both our explicit and implicit options differ from the explicit options of Nöldeke and Schmidt in not requiring a fixed strike price. Instead, the strike price is provided by an external expert for the explicit options, and by the trade buyer or the IPO price for the implicit options. On the second dimension, we differ from both Hart and Moore and Nöldeke and Schmidt in that we do not assume a one-sided distribution of bargaining power in renegotiation. Instead, we assume simple Nash bargaining powers. On the third dimension, we differ from both Hart and Moore and Nöldeke and Schmidt in considering cooperative investments. This difference allows us to highlight what we believe is our main contribution.

In our view, an important contribution of our paper is to show how, when the parties cannot commit not to renegotiate a contract, clauses such as those found in shareholder agreements can be used to constrain renegotiation so as to maintain the parties' incentives to make the first-best ex ante investments. The original contract specifies the parties' initial stakes in the firm. This would induce firstbest ex ante investments if the parties could commit not to renegotiate their shares of the final payoff. The clauses in shareholder agreements constrain renegotiation so as to maintain the shares implied by the parties' initial stakes, despite the need to change the parties' ownership stakes in the firm. ${ }^{4}$

Joint ventures and venture capital have received much attention in the academic literature. ${ }^{5}$ However, only recently has the literature considered some of the clauses found in shareholder agreements. Aghion, Bolton, and Tirole (2004) provide an explanation for drag-along rights, demand rights, and piggyback rights

\section{See also Maskin and Tirole (1999).}

4. The combined contract is in a sense renegotiation-proof. However, unlike more usual renegotiation-proof contracts, the combined contract does not set the parties' initial stakes equal to what they would otherwise be renegotiated to.

5. Allen and Phillips (2000), Bhattacharyya and Lafontaine (1995), Darrough and Stoughton (1989), Hauswald and Hege (2004), McConnell and Nantell (1985), Mohanram and Nanda (1998), Oxley (1997), Pisano (1989), Rey and Tirole (1998), and Robinson and Stuart (2002) study joint ventures and alliances. Aghion, Bolton, and Tirole (2004), Berglöf (1994), Cornelli and Yosha (2003), Dessein (2005), Gompers (1995), Hellmann (1998, 2001), Inderst and Müller (2004), Kaplan and Strömberg (2003, 2004), Kirilenko (2001), Neher (1999), Repullo and Suarez (1998), and Schmidt (2003) study venture capital contracts. 
based on the desire for liquidity. The focus on liquidity is appropriate for venture capital investments which are generally sold in a public offering, but perhaps less so for joint ventures, which rarely are. That similar clauses are found in joint venture and venture capital contracts suggests that there may be more to these clauses than the desire for liquidity. Kahan (2000) values various forms of the right of first refusal, which gives the remaining partners priority over a trade buyer in buying a departing partner's stake. Hauswald and Hege (2004) find that joint venture contracts that include explicit options are more likely to depart from 50-50 ownership and interpret this to imply that the protection options afford minorities makes parties more willing to contemplate minority positions.

To illustrate our analysis, we consider a joint venture contract that was much in the news in the early months of 2005: the contract between General Motors (GM) and Fiat S.p.A (Fiat). ${ }^{6}$ The two companies entered into a joint venture in 2000. The venture was dissolved in early 2005. During the life of the joint venture, Fiat owned $80 \%$ of its auto division, Fiat Auto, and GM the remaining 20\%. The contract granted Fiat the right to put its $80 \%$ stake in Fiat Auto to GM, for a period commencing 42 months and ending 9 years after the signing of the contract. In the event Fiat and GM could not agree on a strike price for the option, the price was to be set equal to Fair market value. Fair market value was to be based on the valuation conducted by two and possibly four investment banks, each bank having conducted its valuation alone. In case Fiat had offered its stake in Fiat Auto to a third party, the contract granted Fiat the right to "drag GM along"- - subject to what was akin to a right of first refusal by GM. ${ }^{7}$ Conversely, the contract granted GM the right to "tag Fiat along" in a sale to a third party. The contract could be extended up to a total period of 19 years. In case it was not, or at the conclusion of the 19-year period, the put option and the other rights expired. GM then would have the right to demand of Fiat the listing of Fiat Auto in an IPO. The purpose of our analysis is to shed light on the allocation of options and rights in contracts such as this.

Perhaps the most striking aspect of the contract was the put option. ${ }^{8}$ Put options are generally held by minority shareholders, as a protection against expropriation by the majority shareholder. ${ }^{9}$ Yet this put option was held by the majority shareholder, Fiat, rather than the minority shareholder, GM. Our analysis shows that the nature of the option (put or call) and the identity of the option holder

6. The contract can be found on http://media.gm.com/images/0010filing.htm. Our rendering of the contract, here and in Section 6.3, is necessarily simplified.

7. Note that we do not consider the right of first refusal in the present paper.

8. On the dissolution of the joint venture, GM paid Fiat $€ 1 \mathrm{bn}(\$ 1.3 \mathrm{bn})$ in order to buy back the put option it had written to Fiat.

9. Lerner and Schoar (2003) find that private equity contracts in emerging markets often include the option for minority investors to put their stakes to the majority owner. Minority investors readily admit that these put options are intended to protect them from expropriation by the majority owner. 
(majority or minority shareholder) jointly depend on the nature of the ex post problem (transfer or investment) and the distribution of bargaining power. When the minority shareholder's stake must be increased in order for that shareholder to be induced to make an ex post investment, an option at fair value is required in order for the parties' shares of the payoff to be maintained despite the change in the parties' stakes. The option takes the form of a put option held by the majority shareholder, rather than a call option held by the minority shareholder, when bargaining — which must be prevented — would favor the latter shareholder over the former.

We proceed as follows. Section 2 presents the initial setting and outlines the problems that would arise in the absence of the clauses. Subsequent sections show how the various clauses we consider can remedy these problems. We analyze the case where ownership of the firm should remain with the founding parties in Section 3 and that where it should be transferred to a trade buyer in Section 4. We establish the result that the clauses taken together elicit the desired ex ante investments in Section 5. In Section 6, we extend the analysis to the case where the firm should be taken public in an IPO and the case of ex post investment instead of transfers, and apply our analysis to the joint venture contract between GM and Fiat. We discuss three limitations of our analysis in Section 7. Section 8 concludes with a discussion of the similarities and differences between shareholder agreements and the rules and regulations that govern tender offers and the sale of control blocks. An appendix contains a brief overview of the clauses found in standard shareholder agreements.

\section{The Baseline Model}

\subsection{The Initial Setting}

Two parties $a$ and $b$ jointly start a firm. They sign a contract that allocates initial stakes $\gamma$ to party $a$ and $1-\gamma$ to party $b$. The contract may include put and call options, tag-along rights, and drag-along rights. ${ }^{10}$ The put and the call require the setting of a strike price. This is typically taken to be the "fair" value of the firm, and shareholder agreements include a clause outlining how this is to be determined. A popular option is to delegate valuation to an external expert, such as an investment bank or a firm of accountants. Alternatively, the clause may set out a formula for how value is to be determined. For the purpose of our analysis, it is necessary not that the valuation be perfect but that it be unbiased. We consider

10. We shall briefly analyze demand rights and piggyback rights in Section 6.1. This is because the analysis of demand rights and piggyback rights closely follows that of drag-along rights and tag-along rights, respectively. We analyze catch-up clauses in Section 6.2. 
the fair value of the firm to be the value of the firm under the conditions that result from the exercise of the option.

Each party must make a non-contractible investment towards the success of the firm. Let $i_{n}$ denote the investment made by party $n$ at a cost $(1 / 2) c_{n} i_{n}^{2}$, $n \in\{a, b\}$.

Once the investments have been made, the firm can remain the property of the two founding parties $a$ and $b$, or one or both founding parties can sell their stake to a trade buyer $t$ in a trade sale. We assume that the trade buyer has no bargaining power when bargaining with one or both founding parties.

There are two non-contractible states. In state $s_{t}$, the acquisition of a majority stake in the firm by the trade buyer increases the value of the firm. In state $s_{f}$, such acquisition decreases the value of the firm. ${ }^{11}$ We denote $p_{t}$ the probability of state $s_{t}$ and $p_{f}$ the probability of state $s_{f}, p_{t}+p_{f}=1$. We say that the firm is in use $u=t$ when the trade buyer has acquired a majority stake or the entire firm. We say that the firm is in use $u=f$ when the trade buyer has acquired a minority stake or none at all.

The value of the firm in use $u \in\{t, f\}$ and state $s \in\left\{s_{t}, s_{f}\right\}$ is $V_{u}(s)$ $\min \left\{i_{a}, i_{b}\right\} \equiv V_{u}(s) I .{ }^{12}$ From the definition of the states $s_{t}$ and $s_{f}$, we have $V_{t}\left(s_{t}\right)>V_{f}\left(s_{t}\right)$ and $V_{f}\left(s_{f}\right)>V_{t}\left(s_{f}\right)$.

We consider the possibility of value-decreasing ex post transfers from the firm. The transfers we have in mind are very general. They may take the form of what Johnson et al. (2000) call "tunneling"- theft by the majority owner of the firm. They may consist in having one or the other owner use know-how it has acquired from the firm to compete with the firm. They may consist in having the minority owner use any blocking power it may have to frustrate even valuecreating initiatives on the part of the majority owner, if these should adversely affect the minority owner.

Regardless of the specific nature of the transfer, we assume that only one party can engage in a transfer. This assumption simplifies the analysis and delivers clear testable implications as to which party should have what rights under what circumstances. ${ }^{13}$ We consider in turn (i) the case where one of the two founding parties, say party $a$, can engage in transfers and (ii) the case where the trade buyer $t$ can do so.

11. The subscript $f$ stands for founding: it is used to refer to a situation in which ownership of the firm should remain with the founding parties.

12. We use the Leontieff production function $I \equiv \min \left\{i_{a}, i_{b}\right\}$ because it imparts a very simple structure to the contract that would induce the parties to make the first-best ex ante investment, if the parties could commit not to renegotiate their shares of the final payoff. This allows us to concentrate on the role of the shareholder agreement in constraining renegotiation so as to maintain the parties' shares yet achieve the necessary changes in the parties' stakes.

13. We discuss the case where more than one party can engage in transfers in Sections 6.2 and 7. 
A transfer decreases firm value by a constant fraction $\Delta, 0<\Delta<1$, from $V_{u}(s) I$ to $V_{u}(s) I(1-\Delta)$ in use $u \in\{t, f\}$ and state $s \in\left\{s_{t}, s_{f}\right\}$. The benefit of the transfer to the party that has engaged in the transfer is $\alpha V_{u}(s) I \Delta$. Transfers are value-decreasing: $\alpha<1$. However, as the full cost of the transfer is shared by the owners of the firm whereas the benefits are received only by the party engaging in the transfer, a party with stake $\gamma$ (respectively, $1-\gamma$ ) will engage in a transfer if $\alpha>\gamma$ (respectively, $\alpha>1-\gamma$ ). We assume that $\alpha>1 / 2$. This implies that only by giving a party that has the ability to engage in transfers a majority stake in the firm - or by buying him out completely — can that party be deterred from engaging in transfers.

We note that the interpretation of $\Delta>0$ as transfer can be changed to one of $\Delta<0$ as investment, in which case a party with stake $\gamma$ (respectively, $1-\gamma$ ) will not make a value-creating ex post investment if $\alpha>\gamma$ (respectively, $\alpha>1-\gamma$ ). We deal first with transfers, which are a foremost concern of parties in joint ventures (Doz and Hamel 1998; Reich and Mankin 1986). We return to the latter interpretation in Section 6.2.

We allow the founding parties $a$ and $b$ to renegotiate the original contract after the state is realized but before transfers or a trade sale have taken place. Renegotiation takes the form of a standard asymmetric Nash bargaining game, in which parties $a$ and $b$ have bargaining power $\beta(s)$ and $1-\beta(s)$, respectively. Note that bargaining power may vary with the realized state $s \in\left\{s_{t}, s_{f}\right\}$.

To summarize, the timing of the model is as follows:

(1) At time 0 , parties $a$ and $b$ sign a contract specifying their initial stakes $\gamma$ and $1-\gamma$, respectively. The contract may contain clauses that allocate rights to the parties.

(2) At time 1, parties $a$ and $b$ invest $i_{a}$ and $i_{b}$, respectively.

(3) At time 2, the state is realized. Parties $a$ and $b$ may renegotiate the original contract and/or exercise the relevant rights.

(4) At time 3, a trade sale and/or a transfer may take place. The payoffs are received.

\subsection{Preliminary Analysis Absent the Clauses}

We now discuss the problems that arise in the absence of the clauses. In subsequent sections, we will show how the various clauses we consider can remedy these problems.

In the spirit of backward induction, we first consider the ex post stakes that prevent value-decreasing transfers. In state $s_{f}$, in case party $a$ can engage in a transfer and that party's initial stake $\gamma$ is less than $\alpha$, the parties renegotiate the original stakes so as to increase party $a$ 's stake from $\gamma<\alpha$ to $\gamma^{r} \geq \alpha$.

In state $s_{t}$, the trade buyer must acquire a majority stake for the value of the firm to be increased from $V_{f}\left(s_{t}\right) I$ to $V_{t}\left(s_{t}\right) I$ absent transfers. If $a$ can engage in 
a transfer, the trade buyer must buy out party $a$. This is because the requirement that the trade buyer acquire a majority stake in the firm in state $s_{t}$ precludes the prevention of transfers by party $a$ by giving $a$ a majority stake in the firm. In case it is the trade buyer who can engage in a transfer, the trade buyer's majority stake in the firm must be at least $\alpha>1 / 2$.

We now turn to the investment stage. We consider the first-best investments $i_{a}^{\mathrm{FB}}$ and $i_{b}^{\mathrm{FB}}$. These are the solution to the problem

$$
\max _{\hat{\imath}_{a}, \hat{\iota}_{b}} p_{f} V_{f}\left(s_{f}\right) \min \left\{\hat{\imath}_{a}, \hat{\imath}_{b}\right\}+p_{t} V_{t}\left(s_{t}\right) \min \left\{\hat{\imath}_{a}, \hat{\imath}_{b}\right\}-\frac{1}{2} c_{a} \hat{\imath}_{a}^{2}-\frac{1}{2} c_{b} \hat{\imath}_{b}^{2} .
$$

From the first-order conditions, first-best investments satisfy

$$
I^{\mathrm{FB}}=i_{a}^{\mathrm{FB}}=i_{b}^{\mathrm{FB}}=\frac{p_{f} V_{f}\left(s_{f}\right)+p_{t} V_{t}\left(s_{t}\right)}{c_{a}+c_{b}} .
$$

Note that the parties make identical investments at the first-best. This is because any difference in investment $\left|i_{a}-i_{b}\right|$ would be wasted given the Leontieff production function $\min \left\{i_{a}, i_{b}\right\}$.

We now show that-if the founding parties can commit to retain their shares in state $s_{f}$ and to sell them to the trade buyer in state $s_{t}$, and if party $a$ can commit not to engage in transfers in state $s_{f}$-the first-best investments $i_{a}^{\mathrm{FB}}$ and $i_{b}^{\mathrm{FB}}$ can be elicited despite the problem of double moral hazard (Holmström, 1982). ${ }^{14}$ This is because the Leontieff production function makes each party the unique residual claimant to the investment he makes at the optimum (Hauswald and Hege 2004; Legros and Matthews 1993).

PROPOSITION 1. If the founding parties can commit to retain their shares in state $s_{f}$ and to sell them to the trade buyer in state $s_{t}$, and if party a can commit not to engage in transfers in state $s_{f}$, the parties can be induced to make the first-best investments when given initial stakes $\gamma_{0}$ and $1-\gamma_{0}$ with

$$
\gamma_{0}=\frac{c_{a}}{c_{a}+c_{b}} .
$$

Proof. The problems solved by parties $a$ and $b$ are

$$
\max _{\hat{\imath}_{a}} p_{f} \gamma V_{f}\left(s_{f}\right) \min \left\{\hat{\imath}_{a}, i_{b}\right\}+p_{t} \gamma V_{t}\left(s_{t}\right) \min \left\{\hat{\imath}_{a}, i_{b}\right\}-\frac{1}{2} c_{a} \hat{\imath}_{a}^{2}
$$

and

$$
\max _{\hat{\imath}_{b}} p_{f}(1-\gamma) V_{f}\left(s_{f}\right) \min \left\{i_{a}, \hat{\imath}_{b}\right\}+p_{t}(1-\gamma) V_{t}\left(s_{t}\right) \min \left\{i_{a}, \hat{\imath}_{b}\right\}-\frac{1}{2} c_{b} \hat{\imath}_{b}^{2} .
$$

14. Note that the conditions specified are sufficient but need not be necessary. 
These have first-order conditions

$$
\left[p_{f} \gamma V_{f}\left(s_{f}\right)+p_{t} \gamma V_{t}\left(s_{t}\right)\right] 1_{i_{a} \leqslant i_{b}}=c_{a} i_{a}
$$

and

$$
\left[p_{f}(1-\gamma) V_{f}\left(s_{f}\right)+p_{t}(1-\gamma) V_{t}\left(s_{t}\right)\right] 1_{i_{a} \geqslant i_{b}}=c_{b} i_{b},
$$

where $1_{[\cdots]}$ denotes the indicator function. The solution must satisfy $i_{a}=i_{b}$. It now suffices to note that setting $\gamma=c_{a} /\left(c_{a}+c_{b}\right) \equiv \gamma_{0}$ yields the desired result.

Note that $\gamma_{0} \lessgtr 1 / 2$ as $c_{a} \lessgtr c_{b}$. The party with higher cost must be given a larger stake in order to be induced to make the same investment as his lower cost counterpart.

Of course, it is difficult if not impossible for the parties credibly to make such commitments as in Proposition 1, because a founding party who can increase his payoff by reneging assuredly will do so. Renegotiation may ensue, ensuring ex post efficiency but distorting ex ante investment. ${ }^{15}$

What then is the value of Proposition 1? The proposition shows that a sufficient condition for the first-best investments to be elicited is to make the founding parties share the final payoff in the proportions $\gamma_{0}=c_{a} /\left(c_{a}+c_{b}\right)$ and $1-\gamma_{0}=c_{b} /\left(c_{a}+c_{b}\right)$. Thus, when state $s_{f}$ is realized, party $a$ can engage in transfers, and the parties' stakes in the firm must be altered from the initial proportions $(\gamma, 1-\gamma)$ to the proportions $\left(\gamma^{r}, 1-\gamma^{r}\right)$, the increase in value made possible by such change must be shared so as to let the parties share in the final payoff in the proportions $\left(\gamma_{0}, 1-\gamma_{0}\right)$. Similarly, when state $s_{t}$ is realized and a majority stake in the firm is to be sold to a trade buyer, the proceeds from the sale must be shared such that the founding parties' shares of the final payoff are in the proportions $\left(\gamma_{0}, 1-\gamma_{0}\right)$.

It is clear that this will not be the case absent the clauses, for the parties' payoffs in renegotiation are determined by their bargaining powers, and these will generally not be such as to make the parties share in the final payoff in the desired proportions. ${ }^{16}$ We argue in the sections that follow that the various clauses found

15. This is a well-known result; see Hart (1995), for example.

16. Could the desired result be obtained by having the parties enter into two forward contracts, a first forward contract for party $b$ to sell a stake $\gamma^{r}-\gamma$ at fair value to party $a$, and a second forward contract for the two parties jointly to sell their stakes to the trade buyer? Yes, if these two contracts can be made state-contingent, the first contract valid in state $s_{f}$ only and the second in state $s_{t}$. It then suffices to set $\gamma=\gamma_{0}$. No, if the states are non-contractible. In such case, the decision to abide by the terms of a contract must be voluntary, for it is impossible to mandate compulsory compliance with two mutually exclusive contracts. Voluntary compliance provides a party with strong bargaining power with the opportunity to increase through ex post bargaining his share of the payoff, by withholding agreement to the terms of a contract. For example, the party with strong bargaining power in state $s_{t}$ can withhold agreement to sell the firm to the trade buyer in that state, in the hope of augmenting his share of the payoff through ex post bargaining intended to bring him to agree to such sale. 
in shareholder agreements have the effect of constraining renegotiation so as to maintain the founding parties' shares of the final payoff in the initial proportions, $\gamma$ and $1-\gamma$. It then suffices to set $\gamma=\gamma_{0}$ to obtain the desired shares of the final payoff, thereby eliciting the first-best investments. ${ }^{17}$

We consider the situations that arise in each of the two states $s_{f}$ and $s_{t}$, with party $a$ or the trade buyer having the ability to engage in transfers. For each situation, we show how the founding parties' shares would be altered absent any clause, and identify the clause or clauses that serve to maintain the founding parties' shares. We assume throughout that $\gamma<\alpha$ : Only if the inequality is true do ex post transfers by party $a$ constitute a problem. Transfers by the trade buyer require either $\gamma<\alpha$ or $1-\gamma<\alpha$.

\section{The State $s_{f}$ : Put Options and Tag-along Rights}

We consider the state $s_{f}$ in which majority ownership of the firm should remain with a founding party. We first consider the case where it is party $a$ that can engage in transfers, and derive a rationale for put options in shareholder agreements.

\subsection{Party a Can Transfer: Put Options}

As $\gamma<\alpha$, party $a$ should increase his stake from $\gamma$ to $\gamma^{r} \geqslant \alpha$. We show in Proposition 2 that a put option held by party $b$ to put a stake $\gamma^{r}-\gamma$ to party $a$ at fair value serves to change the parties' stakes from $(\gamma, 1-\gamma)$ to $\left(\gamma^{r}, 1-\gamma^{r}\right)$ while maintaining the parties' shares of the payoff in the initial proportions $\gamma$ and $1-\gamma$.

PROPOSITION 2. A put option at fair value serves to change the founding parties' stakes in the firm while maintaining the parties' initial shares of the payoff.

Proof. Let $F$ denote the fair value of the firm under the conditions that result from the exercise of the option: $F=V_{f}\left(s_{f}\right) I$. The strike price of the option therefore equals $\left(\gamma^{r}-\gamma\right) V_{f}\left(s_{f}\right) I$, thereby ensuring that party $b$ does indeed exercise the put option.

17. An alternative to the use of the clauses is to adjust the parties' initial stakes for the expected effect of renegotiation. For example, a founding party that expects to see his share of the payoff decreased by renegotiation may be allocated a high initial stake in the firm. A limitation of this solution is that the necessary adjustments to the parties' initial stakes may be so large as to take these below 0 or above 1 . This will be the case where there is a large discrepancy in the partners' bargaining power, a far from uncommon situation. In venture capital, for example, the upper hand generally belongs to the venture capitalist. Adjusting for the expected effect of renegotiation may imply giving the entrepreneur an initial stake greater than 1, clearly an impossibility. Even a stake less than 1 but well above 0.5 may be infeasible because of control considerations. 
The preceding implies that, when making the ex ante investments, the parties' payoffs conditional on the state $s_{f}$ being realized are

$$
\gamma^{r} V_{f}\left(s_{f}\right) I-\left(\gamma^{r}-\gamma\right) F=\gamma^{r} V_{f}\left(s_{f}\right) I-\left(\gamma^{r}-\gamma\right) V_{f}\left(s_{f}\right) I=\gamma V_{f}\left(s_{f}\right)
$$

for party $a$ and $(1-\gamma) V_{f}\left(s_{f}\right) I$ for party $b$. The parties' payoffs have been maintained in the initial proportions $\gamma$ and $1-\gamma$.

Setting the strike price of the option equal to fair value denies both parties any direct benefit from the exercise of the option. This maintains the parties' payoffs in the initial proportions $\gamma$ and $1-\gamma$. Nonetheless, by changing the parties' stakes from $(\gamma, 1-\gamma)$ to $\left(\gamma^{r}, 1-\gamma^{r}\right)$, the exercise of the option precludes transfers by party $a$.

Clearly, a call option held by party $a$ to call a stake $\gamma^{r}-\gamma$ from party $b$ at fair value would - if exercised - achieve the same result as the put option just analyzed. However, such an option would not be exercised by $a$, who would instead seek to exploit the leverage he is afforded by the ability to engage in transfers. ${ }^{18}$ To see this, note that party $a$ 's payoff from bargaining with $b$ is

$$
\begin{aligned}
& \gamma V_{f}\left(s_{f}\right) I(1-\Delta)+\alpha V_{f}\left(s_{f}\right) I \Delta \\
& \quad+\beta\left(s_{f}\right)\left[V_{f}\left(s_{f}\right) I-\left[V_{f}\left(s_{f}\right) I(1-\Delta)+\alpha V_{f}\left(s_{f}\right) I \Delta\right]\right] \\
& \quad \geqslant \gamma V_{f}\left(s_{f}\right) I(1-\Delta)+\alpha V_{f}\left(s_{f}\right) I \Delta \\
& \quad>\gamma V_{f}\left(s_{f}\right) I
\end{aligned}
$$

where the last inequality is true by the assumption that $\gamma<\alpha$. As $\gamma V_{f}\left(s_{f}\right) I$ constitutes party $a$ 's payoff from exercising the call, it is clear that $a$ would let the option expire and bargain with $b$. Conversely, party $b$ will exercise the put option in order to deny party $a$ the benefit of exploiting the leverage $a$ is afforded by his ability to engage in transfers.

Note that party $b$ must be granted the put option regardless of (i) the size of his stake in the firm, whether a majority stake or a minority, and (ii) his bargaining power. In particular, even a majority shareholder with strong bargaining power may need to be protected by a put option. This is because even a minority shareholder with weak bargaining power has the ability to increase his share of the payoff by engaging in transfers.

The presence of the trade buyer leaves the preceding analysis unchanged. Neither founding party profits from selling his stake to the trade buyer. Indeed, the parties would see their combined payoff decrease if the majority owner were to sell his stake to the trade buyer, as this would decrease the value of the firm from $V_{f}\left(s_{f}\right)$ to $V_{t}\left(s_{f}\right)$.

18. We provide a rationale for call options in Section 6.2. 


\subsection{The Trade Buyer Can Transfer: Tag-along Rights}

We now consider the case where it is the trade buyer who can engage in transfers, and derive a rationale for tag-along rights in shareholder agreements.

We saw in Section 3.1 that the ability to engage in transfers is a source of leverage to the party endowed with that ability. We note now that it may also be a source of leverage to a party who sells his stake to someone who can engage in transfers.

To see this, denote the founding party that owns a majority stake in the firm by $M$, and the founding party that owns a minority stake by $m .{ }^{19}$ We show that having both founding parties keep their stakes in the firm is not a Nash equilibrium. Party $m$ clearly can profit from selling his stake to the trade buyer when party $M$ keeps his stake. The value of party $m$ 's stake to the trade buyer will be received by party $m$ in its entirety, as the trade buyer has no bargaining power when bargaining with a founding party. This value is

$$
\gamma_{m} V_{f}\left(s_{f}\right) I(1-\Delta)+\alpha V_{f}\left(s_{f}\right) I \Delta>\gamma_{m} V_{f}\left(s_{f}\right) I,
$$

where the inequality is true by the assumption that $\alpha>1 / 2$ and the definition of $m$ as the minority owner, $\gamma_{m}<1 / 2$. Party $m$ 's gain is party $M$ 's loss. ${ }^{20}$

If $\gamma_{M}<\alpha$, party $M$ might profit from selling his stake to the trade buyer when party $m$ keeps his stake. This would be the case if

$$
\gamma_{M} V_{t}\left(s_{f}\right) I(1-\Delta)+\alpha V_{t}\left(s_{f}\right) I \Delta>\gamma_{M} V_{f}\left(s_{f}\right) I .
$$

Of course, no sale to the trade buyer will take place in equilibrium, for such sale-whether of a minority stake that affords the trade buyer the opportunity to engage in transfers or a majority stake that lowers firm value absent transfers from $V_{f}\left(s_{f}\right)$ to $V_{t}\left(s_{f}\right)$-is value-decreasing. However, the bargaining intended to prevent such sale will alter the parties' shares of the final payoff, thereby distorting the parties' ex ante investments.

Tag-along rights serve to preclude such bargaining. By granting a founding party the right to make the sale of a stake by the other founding party conditional on the acquisition by the buyer of both founding parties' stakes, tag-along rights deny the trade buyer - and therefore the founding party threatening to sell his

19. $M=a$ and $m=b$ if $\gamma>1 / 2$, in which case $\gamma_{M}=\gamma$ and $\gamma_{m}=1-\gamma ; M=b$ and $m=a$ if $\gamma<1 / 2$, in which case $\gamma_{M}=1-\gamma$ and $\gamma_{m}=\gamma$.

20. Party $M$ 's payoff becomes

$$
\begin{aligned}
V_{f}\left(s_{f}\right) I-\left[\gamma_{m} V_{f}\left(s_{f}\right) I(1-\Delta)+\alpha V_{f}\left(s_{f}\right) I \Delta\right] & <V_{f}\left(s_{f}\right) I-\gamma_{m} V_{f}\left(s_{f}\right) I, \\
& =\left(1-\gamma_{m}\right) V_{f}\left(s_{f}\right) I, \\
& =\gamma_{M} V_{f}\left(s_{f}\right) I,
\end{aligned}
$$

where the inequality is true by inequality (3). 
stake to the trade buyer-the ability to profit from transfers. This is because the trade buyer will not engage in value-decreasing transfers when he is the sole owner of the firm. The highest price the trade buyer can offer for the entire firm is therefore $V_{t}\left(s_{f}\right)$. As $V_{t}\left(s_{f}\right)<V_{f}\left(s_{f}\right)$, neither founding party will sell his stake to the trade buyer. We have thus shown:

PROPOSITION 3. Tag-along rights deny the parties the ability to increase their share of the payoff by threatening to sell their stake to a trade buyer who would decrease the value of the firm through a transfer.

\section{The State $s_{t}$ : Drag-along Rights and Tag-along Rights}

We now consider the state $s_{t}$, in which majority ownership of the firm should be acquired by the trade buyer. Again, we distinguish between the case where party $a$ can engage in transfers and that where the trade buyer can. We also distinguish between the case where $a$ is majority owner of the firm and that where $b$ is. We establish a rationale for drag-along rights and establish an alternative rationale for tag-along rights.

\subsection{Party a Can Transfer: Drag-along Rights}

Assume party $a$ is minority owner of the firm who can engage in transfers. As is clear from the definition of state $s_{t}$, both founding parties gain from the sale of a majority stake to the trade buyer. A sale must include the sale of party $a$ 's entire stake, for $a$ would otherwise engage in transfers. As $a$ is a minority owner, $b$ must join $a$ in selling at least part of his stake to the trade buyer.

We first show that a concurrent sale by the two founding parties is not a Nash equilibrium. By holding out on a concurrent sale with $b, a$ can appropriate to himself the entirety of the increase in value made possible by the preclusion of transfers. ${ }^{21}$ By holding out on a concurrent sale with $a$, party $b$ can appropriate

21. Formally,

$$
\begin{aligned}
& \gamma V_{t}\left(s_{t}\right) I(1-\Delta)+\alpha V_{t}\left(s_{t}\right) I \Delta+\left[V_{t}\left(s_{t}\right) I-\left[V_{t}\left(s_{t}\right) I(1-\Delta)+\alpha V_{t}\left(s_{t}\right) I \Delta\right]\right] \\
& \quad=\gamma V_{t}\left(s_{t}\right) I+(1-\gamma) V_{t}\left(s_{t}\right) I \Delta, \\
& \quad>\gamma V_{t}\left(s_{t}\right) I .
\end{aligned}
$$


to himself the entirety of the gains made possible by the transfer of majority ownership from a founding party to the trade buyer. ${ }^{22}$

As the sale to the trade buyer is value-increasing, the parties will seek to avoid hold-out on such sale by bargaining. However, bargaining alters the parties' shares of the final payoff and distorts investment.

An alternative to bargaining is to grant the party that would be penalized by bargaining the right to force his counterpart to join him in selling his stake to the trade buyer. The counterpart does not do so of his own accord, for his benefit from bargaining prompts him to threaten hold-out. Drag-along rights prevent this. We have thus shown:

PROPOSITION 4. Drag-along rights deny the parties the ability to increase their share of the payoff by threatening to hold out on a value-increasing trade sale.

What if party $a$ is majority owner of the firm? In such case, only hold-out by $a$ is of concern. This is because $a$ can appropriate both the gains from precluding transfers and those from transferring majority ownership to the trade buyer ${ }^{23}$ Party $b$ must be granted the right to drag $a$ along in order for $b$ to maintain his share of the payoff.

Recall from Section 3.1 that party $b$ will be granted a put option when party $a$ can engage in transfers. Does a conflict arise between $b$ 's put option and $a$ 's drag-along rights, in case $a$ should have such rights? A conflict between two clauses arises when the threatened exercise of one clause conflicts with the actual exercise of the other, thereby leading to ex post bargaining from which the party threatening exercise of the first clause hopes to profit. No such threat is credible in the present case. Party $a$ will not sell his stake to the trade buyer in state $s_{f}$, for such sale decreases the value of $a$ 's own stake. A threat by $a$ to exercise its

22. Formally,

$$
\begin{aligned}
(1-\gamma) V_{f}\left(s_{t}\right) I+\left[V_{t}\left(s_{t}\right) I-V_{f}\left(s_{t}\right) I\right] & =(1-\gamma) V_{t}\left(s_{t}\right) I+\gamma\left[V_{t}\left(s_{t}\right) I-V_{f}\left(s_{t}\right) I\right], \\
& >(1-\gamma) V_{t}\left(s_{t}\right) I,
\end{aligned}
$$

where the inequality is true by $V_{t}\left(s_{t}\right)>V_{f}\left(s_{t}\right)$. Note that there is no incentive for one founding party to precede the other in selling to the trade buyer. As noted in Section 3.2, the incentive to do so is to exploit the trade buyer's ability to engage in transfers. There is not such ability in the present case.

23. Formally,

$$
\begin{aligned}
& \gamma V_{f}\left(s_{t}\right) I(1-\Delta)+\alpha V_{f}\left(s_{t}\right) I \Delta+\left[V_{t}\left(s_{t}\right) I-\left[V_{f}\left(s_{t}\right) I(1-\Delta)+\alpha V_{f}\left(s_{t}\right) I \Delta\right]\right], \\
& \quad=\gamma V_{t}\left(s_{t}\right) I+(1-\gamma) V_{t}\left(s_{t}\right) I \Delta+(1-\gamma)\left[V_{t}\left(s_{t}\right) I-V_{f}\left(s_{t}\right) I\right](1-\Delta), \\
& \quad>\gamma V_{t}\left(s_{t}\right) I+(1-\gamma) V_{t}\left(s_{t}\right) I \Delta, \\
& \quad>\gamma V_{t}\left(s_{t}\right) I
\end{aligned}
$$

where the first inequality is true by $V_{t}\left(s_{t}\right)>V_{f}\left(s_{t}\right)$. 
drag-along rights in state $s_{f}$ is therefore not credible. ${ }^{24}$ Nor is a threat by $b$ to exercise his put option in state $s_{t}$. Party $b$ cannot profit from making such a threat, to which $a$ would respond by buying $b$ 's stake at fair value and selling the entire firm to the trade buyer.

\subsection{The Trade Buyer Can Transfer: Tag-along Rights and Drag-along Rights}

We now consider the case where it is the trade buyer who can engage in transfers. As in Section 3.2, a founding party can seek to exploit the trade buyer's ability to engage in transfers. If $\gamma_{M}<\alpha$, the majority owner $M$ clearly can profit from preceding his minority counterpart $m$ in selling out to the trade buyer, for the trade buyer values $M$ 's stake at

$$
\gamma_{M} V_{t}\left(s_{t}\right) I(1-\Delta)+\alpha V_{t}\left(s_{t}\right) I \Delta>\gamma_{M} V_{t}\left(s_{t}\right) I .
$$

Party $m$ too can profit from preceding his counterpart in selling his stake to the trade buyer, if

$$
\gamma_{m} V_{f}\left(s_{t}\right) I(1-\Delta)+\alpha V_{f}\left(s_{t}\right) I \Delta>\gamma_{m} V_{t}\left(s_{t}\right) I .
$$

Again, as in Section 3.2, a founding party's gain is the other's loss. ${ }^{25}$ And, as in Section 3.2, the resulting distortion in the founding parties' shares of the final payoff can be avoided by granting one founding party the right to tag along the other founding party in a trade sale. This is because tag-along rights require that the trade buyer's purchase of the founding parties' stakes be made on identical terms and conditions, thereby ensuring that the parties' shares of the proceeds from the trade sale are in proportion to their stakes, specifically $\gamma$ and $1-\gamma$. The difference between Section 3.2 and the present section is that the sale to the trade buyer is desirable in the present case, as $V_{t}\left(s_{t}\right)>V_{f}\left(s_{t}\right)$. We thus have the following result.

PROPOSITION 5. Tag-along rights deny the parties the ability to increase their share of the payoff by preceding the other parties in selling their stake to a trade buyer who will increase the value of the firm.

24. The same reasoning shows that party $b$ will not threaten to exercise his drag-along rights in state $s_{f}$, in case it is $b$ rather than $a$ that should be granted such rights.

25. For example, if party $M$ preceded party $m$ in selling his stake to the trade buyer, $m$ 's payoff would be

$$
\begin{aligned}
V_{t}\left(s_{t}\right) I-\left[\gamma_{M} V_{t}\left(s_{t}\right) I(1-\Delta)+\alpha V_{t}\left(s_{t}\right) I \Delta\right] & <V_{t}\left(s_{t}\right)-\gamma_{M} V_{t}\left(s_{t}\right) I, \\
& =\left(1-\gamma_{M}\right) V_{t}\left(s_{t}\right) I, \\
& =\gamma_{m} V_{t}\left(s_{t}\right) I,
\end{aligned}
$$

where the inequality is true by inequality (5). 
What if neither inequality (5) nor inequality (6) is true? Clearly, neither founding party will wish to precede the other in selling his stake to the trade buyer in such case. But would a founding party wish to hold out on a concurrent sale to the trade buyer? Party $m$ clearly will not, for he has no leverage absent the ability to engage in transfers. In contrast, party $M$ will, for he can thereby appropriate the entire gain from transferring majority ownership to the trade buyer. ${ }^{26}$ As in Section 4.1, party $m$ must therefore be granted the right to drag party $M$ along.

When the trade buyer can engage in transfers, both Section 3.2 and the present section suggest that one or both parties should be granted tag-along rights and, possibly, that the minority party should be granted drag-along rights. ${ }^{27}$ These rights are not in conflict. Tag-along and drag-along rights operate in exactly the same manner: they force a trade buyer to treat both parties identically. They thereby make it impossible for one founding party to profit at the expense of the other from the presence of the trade buyer.

\section{Investments and Initial Stakes}

The preceding sections show that the various clauses we consider constrain renegotiation so as to make the founding parties' shares of the final payoff equal to their initial stakes in the firm, $\gamma$ and $1-\gamma$. Using Proposition 1, we can then conclude that a sufficient condition for inducing the parties to make the first-best ex ante investments is to set the parties' initial stakes $\gamma$ and $1-\gamma$ equal to $\gamma_{0}$ and $1-\gamma_{0}$, respectively. We have thus shown:

PROPOSITION 6. Put options, tag-along rights, and drag-along rights combine with initial stakes $\gamma_{0}=c_{a} /\left(c_{a}+c_{b}\right)$ and $1-\gamma_{0}=c_{b} /\left(c_{a}+c_{b}\right)$ to induce the founding parties $a$ and $b$ to make the first-best investments $i_{a}^{\mathrm{FB}}$ and $i_{b}^{\mathrm{FB}}$, respectively.

26. Party $M$ 's payoff from holding out is

$$
\begin{aligned}
\gamma_{M} & V_{f}\left(s_{t}\right) I(1-\Delta)+\left[V_{t}\left(s_{t}\right) I-\left[V_{f}\left(s_{t}\right) I(1-\Delta)+\alpha V_{f}\left(s_{t}\right) I \Delta\right]\right] \\
& =V_{t}\left(s_{t}\right) I-\left(1-\gamma_{M}\right) V_{f}\left(s_{t}\right) I(1-\Delta)-\alpha V_{f}\left(s_{t}\right) I \Delta \\
& =V_{t}\left(s_{t}\right) I-\gamma_{m} V_{f}\left(s_{t}\right) I(1-\Delta)-\alpha V_{f}\left(s_{t}\right) I \Delta \\
& >V_{t}\left(s_{t}\right) I-\gamma_{m} V_{t}\left(s_{t}\right) I \\
& =\left(1-\gamma_{m}\right) V_{t}\left(s_{t}\right) I \\
& =\gamma_{M} V_{t}\left(s_{t}\right) I
\end{aligned}
$$

where the inequality is true by the assumption that inequality (6) is false.

27. Drag-along rights granted to minority parties are rarely observed in practice. We discuss why that might be the case in the context of the joint venture between GM and Fiat in Section 6.3. 


\section{Extensions and Applications}

\subsection{An Extension to Demand Rights and Piggy-back Rights}

To analyze demand rights and piggyback rights, we introduce a new state $s=s_{\text {ipo }}$ and a new use of the firm $u=$ ipo. ${ }^{28}$ When the state $s_{\text {ipo }}$ is realized, the firm should be taken public in an IPO: $V_{\text {ipo }}\left(s_{\text {ipo }}\right)>V_{u}\left(s_{\text {ipo }}\right)$ for $u \in\{t, f\}$. We make the important assumption that no transfers are possible once the firm has been listed. Thus, we presume that the various constraints imposed on listed firms by stock exchanges, regulation, and the law for the purpose of protecting shareholders are effective at doing so. ${ }^{29}$

We first note that there is no need for one founding party to drag the other along in state $s_{\text {ipo }}$ : A founding party that sells his stake in the IPO obtains the same payoff regardless of whether he is joined by the other founding party in such sale. There is the need, however, for the denial of veto rights over the decision to take the firm public. This is because the party whose bargaining power is high relative to his stake in the firm would otherwise threaten to veto the IPO, for the purpose of exploiting his favorable bargaining position to increase his share of the final payoff.

To see this, consider the two inequalities that would have to hold simultaneously for neither party to threaten to veto the IPO, when the alternative to the IPO is use $u=f$, with the exercise of the put option intended to preclude transfers if party $a$ should be able to engage in transfers: ${ }^{30}$

$$
\gamma V_{\text {ipo }}\left(s_{\text {ipo }}\right) \geqslant \gamma V_{f}\left(s_{\text {ipo }}\right)+\beta\left(s_{\text {ipo }}\right)\left[V_{\text {ipo }}\left(s_{\text {ipo }}\right)-V_{f}\left(s_{\text {ipo }}\right)\right]
$$

and

$$
(1-\gamma) V_{\text {ipo }}\left(s_{\text {ipo }}\right) \geqslant(1-\gamma) V_{f}\left(s_{\text {ipo }}\right)+\left(1-\beta\left(s_{\text {ipo }}\right)\right)\left[V_{\text {ipo }}\left(s_{\text {ipo }}\right)-V_{f}\left(s_{\text {ipo }}\right)\right] .
$$

From the observation that the sum of the LHS of the preceding inequalities equals the sum of their RHS, it is clear that the two inequalities can hold simultaneously only when they are both equalities. But this requires $a$ 's bargaining power, $\beta\left(s_{\text {ipo }}\right)$, to equal $\gamma$, which generally will not be the case. Instead, party $a$ will threaten to veto the IPO if $\beta\left(s_{\text {ipo }}\right)>\gamma$, and party $b$ otherwise. Party $a$ in the first case, and party $b$ in the second, must therefore be denied the right to veto. This is what demand rights do. We have thus shown:

28. These could have been introduced in the main model of Section 2.1, but were not in order to keep the exposition in Sections 2.2, 3, and 4 relatively simple.

29. This is somewhat of an exaggeration, but may be justified by comparison with the case of unquoted firms.

30. A similar argument can be made when the alternative to the IPO is a trade sale. 
PROPOSITION 7. Demand rights deny the parties the ability to increase their share of the payoff by threatening to veto a value-increasing IPO.

Is there a need for tag-along rights in state $s_{\text {ipo }}$ ? Yes, to the extent that only a limited fraction of the firm can be sold in the IPO, and one founding partypresumably the majority owner $M$-has the ability to include a disproportionate fraction of his own shares in the offering. Tag-along rights then allow the other founding party to include his shares in the offering in proportion to his stake in the firm. In such context, tag-along rights are referred to as piggyback rights. We can thus write:

PROPOSITION 8. Piggyback rights deny the parties the ability to increase their share of the payoff by including a disproportionate fraction of their own shares in the firm's IPO.

\subsection{Transfers as Investment: Call Options, Put Options and Catch-up Clauses}

We now transform the problem of ex post transfers into one of ex post investment. For that purpose, and as noted in Section 2.1, we assume that $\Delta<0$ and define $\Gamma \equiv-\Delta>0$. In contrast to ex post transfers, ex post investment is value-creating as it increases the value of the firm in use $u \in\{t, f\}$ and state $s \in\left\{s_{t}, s_{f}\right\}$ from $V_{u}(s) I$ to $V_{u}(s) I(1+\Gamma)-\alpha V_{u}(s) I \Gamma$ (recall that $\left.1 / 2<\alpha<1\right)$.

The analogue to Proposition 1 in the case of ex post investment can be shown. There is still the need to maintain the founding parties' shares of the final payoff. The payoff is $V_{f}\left(s_{f}\right) I(1+\Gamma)-\alpha V_{f}\left(s_{f}\right) I \Gamma$ in state $s_{f}$ and $V_{t}\left(s_{t}\right)$ in state $s_{t}$ when it is party $a$ that makes the ex post investment. The payoff is $V_{f}\left(s_{f}\right) I$ in state $s_{f}$ and $V_{t}\left(s_{t}\right) I(1+\Gamma)-\alpha V_{t}\left(s_{t}\right) I \Gamma$ in state $s_{t}$ when it is the trade buyer that makes the ex post investment.

We first consider the state $s_{f}$ in the case where it is party $a$ that makes the ex post investment. Recall from Section 2.2 the assumption that $\gamma<\alpha$. Party $a$ 's stake must therefore be increased from $\gamma<\alpha$ to $\gamma^{r} \geq \alpha$ for party $a$ to be induced to make the ex post investment. By analogy to Proposition 2 in Section 3.1, we can show that options at fair value serve to change the founding parties' stakes in the firm while maintaining the parties' initial shares of the payoff. The difference with Section 3.1 is that there is now the need for call options as well as put options. Whether party $a$ has an option to call a stake $\gamma^{r}-\gamma$ from party $b$, or party $b$ has an option to put a stake $\gamma^{r}-\gamma$ to party $a$, depends on the relation between the parties' stakes and their bargaining power. 
TABLE 1. Circumstances and clauses in the case of ex post transfers.

\begin{tabular}{lcc}
\hline & $a$ can transfer & $t$ can transfer \\
\hline$s_{f}$ & put options & tag-along rights \\
$s_{t}$ & drag-along rights & tag-along rights if (5) and/or (6) are true \\
& drag-along rights if both (5) and (6) are false \\
\hline
\end{tabular}

To see this, note that the alternative to option exercise is bargaining. The parties' payoffs in bargaining are

$$
\gamma V_{f}\left(s_{f}\right) I+\beta\left(s_{f}\right)\left[V_{f}\left(s_{f}\right) I(1+\Gamma)-\alpha V_{f}\left(s_{f}\right) I \Gamma-V_{f}\left(s_{f}\right) I\right]
$$

and

$$
(1-\gamma) V_{f}\left(s_{f}\right) I+\left(1-\beta\left(s_{f}\right)\right)\left[V_{f}\left(s_{f}\right) I(1+\Gamma)-\alpha V_{f}\left(s_{f}\right) I \Gamma-V_{f}\left(s_{f}\right) I\right] .
$$

These are to be contrasted with the parties' payoffs from option exercise, which are

$$
\gamma\left(V_{f}\left(s_{f}\right) I(1+\Gamma)-\alpha V_{f}\left(s_{f}\right) I \Gamma\right)
$$

and

$$
(1-\gamma)\left(V_{f}\left(s_{f}\right) I(1+\Gamma)-\alpha V_{f}\left(s_{f}\right) I \Gamma\right) .
$$

When $\beta\left(s_{f}\right)>\gamma$, party $a$ clearly prefers bargaining to the exercise of the call option. Such bargaining must be avoided. It can be avoided by granting party $b$ the option to put the stake $\gamma^{r}-\gamma$ to $a$ when $\beta\left(s_{f}\right)>\gamma$. Conversely, when $\beta\left(s_{f}\right)<\gamma$, it is $a$ who must be granted the option to call the stake $\gamma^{r}-\gamma$ from $b$.

Rather than repeating the analysis of Sections 3.2 and 4 for the case of ex post investment, we summarize the results for the two cases in Tables 1 (ex post transfers) and 2 (ex post investment).

There are two principal differences between Tables 1 and 2 . We have already discussed the first, which is the absence of call options in Table 1. The second is the absence of tag-along rights in Table 2. Both differences can be ascribed to the same basic phenomenon: Ex post transfers allow one founding party to profit at the expense of the other party, whereas ex post investment profits both parties.

TABLE 2. Circumstances and clauses in the case of ex post investment.

\begin{tabular}{lcc}
\hline & $a$ invests & $t$ invests \\
\hline$s_{f}$ & put or call options & no rights needed \\
$s_{t}$ & drag-along rights & drag-along rights \\
\hline
\end{tabular}


The purpose of put options and tag-along rights in Table 1 is to protect the party at whose expense transfers would be and to constrain the party that would profit from transfers. That latter party would be party $a$ in case it is party $a$ who can engage in transfers, and the founding party, who can exploit the trade buyer's ability to engage in transfers in case it is the trade buyer who has such ability. This problem does not arise in the case of ex post investment, so there is no need for tag-along rights, and the choice between put and call options is determined by the relation between the parties' stakes and their bargaining power.

We argued in Section 4 that there is no scope for conflict between the various clauses in the case of ex post transfers. This remains true in the case of ex post investment, with one exception: when party $a$ has a call option and alone is aware of an impending trade sale, $a$ can exercise the option prior to the trade sale in order to profit from the difference between the price paid by the trade buyer and the fair value computed by an external expert who is unaware of the trade sale. Doing so allows the trade buyer to increase his payoff from the trade sale from $\gamma V_{t}\left(s_{t}\right) I$ to

$$
\gamma^{r} V_{t}\left(s_{t}\right) I-\left(\gamma^{r}-\gamma\right)\left[V_{f}\left(s_{f}\right) I(1+\Gamma)-\alpha V_{f}\left(s_{f}\right) I \Gamma\right] .
$$

Catch-up clauses deny $a$ the ability to do so, by granting $b$ a claim to the gain foregone as a result of $a$ 's exercise of the option. ${ }^{31}$

Our analysis has thus far assumed that either party $a$ or the trade buyer can engage in ex post transfers or make an ex post investment. Tables 1 and 2 above, along with the arguments made at the end of Sections 4.1 and 4.2, suggest that the clauses remain effective when both party $a$ and the trade buyer can engage in ex post transfers or make ex post investments. Consider for example the case where both $a$ and the trade buyer can engage in transfers. The only potential conflict is that between party $b$ 's put option and the drag-along rights $a$ may have. ${ }^{32} \mathrm{We}$ argued in Section 4.1 that there is no such conflict in the case where only $a$ can engage in transfers. This remains true when the trade buyer too can do so, for the trade buyer's ability to engage in transfers is neutralized by the founding parties' tag-along and drag-along rights. The same reasoning applies to the case where $a$ and the trade buyer make ex post investments. As noted in the preceding paragraph, catch-up clauses are however necessary in the case where $a$ has a call option.

31. Why do catch-up clauses not apply when a founding party has exercised his put option? Presumably because, unlike a call option, a put option does not afford its holder the opportunity to profit from preceding its partner and the external expert in acquiring information about a trade sale.

32. There is no conflict between party $b$ 's put option and party $a$ 's possible tag-along rights. Party $a$ 's exercise of its tag-along rights requires $b$ to sell his stake to a trade buyer. No such sale takes place when $b$ exercises his put option. As noted at the end of Section 4.2, there is no conflict between the parties' tag-along rights, nor between one party's tag-along rights and the other party's drag-along rights, nor indeed between the parties' drag-along rights. 


\subsection{GM and Fiat}

We now return to the joint venture contract between GM and Fiat described in the Introduction. Recall that the contract granted Fiat the option to put its stake to GM and to drag GM along in the case of a trade sale of Fiat Auto. It granted GM the right to tag along Fiat in such case, as well as the right to demand of Fiat the listing of Fiat Auto.

On the basis of the joint venture contract and various newspaper and magazine articles, we can explain the preceding clauses as follows. The joint venture contract committed GM and Fiat to a number of collaborative ventures in Latin America and in Europe, in powertrain operations, material purchasing activities, and back-office facilities for automotive financing. Beyond these specific collaborative activities and the ex ante investment they involved, there was the issue of whether Fiat Auto could survive as an independent carmaker in an industry that deemed economies of scale to be all-important. If not, GM apparently would have been a natural acquiror. As the acquisition of Fiat Auto by GM likely would have involved significant ex post investment by GM, which would have needed to integrate the operations of Fiat Auto into its own, options were needed in line with the argument made in Section 6.2. These took the form of put options held by Fiat rather than call options held by GM, because a sale of Fiat Auto likely would have taken place under conditions of weak bargaining power for Fiat. ${ }^{33}$

GM was not, however, the only potential buyer of Fiat Auto. ${ }^{34}$ In case Fiat had sold its $80 \%$ stake to a third party, that party may have made an ex post investment benefitting GM as $20 \%$ shareholder in Fiat Auto or engaged in ex post transfers at GM's expense. ${ }^{35}$ As noted in Section 6.2, the first issue called for Fiat's right to drag GM along. In line with our discussion in Section 4.2, the second issue called for GM's right to tag along Fiat.

The best course for Fiat Auto may have been to remain independent. In that case, GM's demand right provided GM with a possible exit route. That it was GM rather that Fiat that had the right to demand a listing is consistent with Fiat having had very high bargaining power in the state where Fiat Auto should have remained independent.

Why did Fiat not have the right to tag along GM and GM the right to drag Fiat along in case GM sold its stake in Fiat Auto? As noted in Sections 3.2 and 4.2 , Fiat's tag-along rights would have been made necessary by the possibility for

33. The sale of Fiat Auto would have been be an admission of defeat by Fiat's controlling Agnelli family, for whom Fiat Auto-founded in 1899 by a group of ex-cavalry officers that included forebear Giovanni Agnelli-has long been the jewel in the family crown. Such sale could therefore have been expected to take place only under very adverse circumstances for Fiat.

34. Daimler-Chrysler had offered to buy Fiat Auto for $€ 12 \mathrm{bn}$ prior to the joint venture with GM.

35. The acquiror would have engaged in ex post transfers in case $\gamma_{M}=80 \%<\alpha$. Recall that the subscript $M$ denotes the majority partner, the acquiror of Fiat's stake in the present case. 
the acquiror of GM's minority stake to engage in transfers. In the absence of such transfers, perhaps due to control considerations, there is no reason to grant Fiat tagalong rights. As noted in Sections 4.1 and 4.2, GM's right to drag Fiat along would have been made necessary by the desire on Fiat's part to appropriate the entire gains made possible by the transfer of majority ownership to the acquiror. This consideration may not have been applicable to Fiat, which would have considered selling Fiat Auto only under very adverse circumstances, in which case its ability to hold out on a trade sale was likely to be very low. ${ }^{36}$

\section{Limitations of Our Analysis}

Our analysis is not without limitations. In particular, three of our assumptions are unlikely always to hold. These are that (1) only one founding party can engage in ex post transfers or make an ex post investment, (2) ex post bargaining power in a given state is known ex ante, and (3) the parties have no wealth constraints.

These assumptions are important to our results, for ex post bargaining can be shown to occur when they are relaxed. Consider for example relaxing assumption (2). If ex post bargaining power is not known ex ante, it may no longer be clear whether a put option should be granted to party $b$ or a call option to party $a$ when the latter party must be induced to make an ex post investment. This is because the option should be granted to the party with bargaining power less than the party's stake in the firm, but who that party is is not known ex ante. The option may be granted to the wrong party, or no option may be granted. In either case, ex post bargaining will take place, altering the parties' shares and distorting their ex ante investment.

Now consider relaxing assumption (1) and assume instead that both founding parties can engage in ex post transfers (party $a$ in state $s_{f a}$ and party $b$ in state $\left.s_{\mathrm{FB}}\right)$. The analysis of Section 3.1 suggests that both parties should be granted put options, $a$ a put option to be exercised in state $s_{\mathrm{FB}}$ and $b$ a put option to be exercised in state $s_{f a}$. It is, however, impossible to constrain each party to exercise his option in the relevant state only. Indeed, $a$ for example surely will threaten to exercise his option in the state $s_{f a}$ in which he can engage in transfers, for the purpose of inducing ex post bargaining intended to increase his share of the payoff. ${ }^{37}$ Whatever the ultimate option allocation, ex post bargaining can be expected to take place, altering the parties' shares and distorting their ex ante investment.

36. An alternative explanation is that drag-along rights may be abused in case side payments from the trade buyer to the minority partner, GM, are possible. We have not considered side payments in our analysis because we have assumed that such payments would be invalidated by courts.

37. Recall from Section 3.1 that the mere ability to engage in transfers increases a party's share of the payoff, regardless of that party's bargaining power. 
Finally, consider relaxing assumption (3). In the presence of wealth constraints, a party may have difficulty paying the strike price of a put option it has written or a call option it has received, or making a desired ex post investment. Ex post bargaining will take place, altering the parties' shares and distorting their ex ante investment.

We believe wealth constraints may provide a possible explanation for the rather dramatic ending of the GM-Fiat joint venture considered in Section 6.3. In early 2005, after much negotiation and not a little bluffing, GM paid Fiat $€ 1$ bn ( $\$ 1.3 \mathrm{bn}$ ) to buy back the put option it had written to Fiat. Why should GM have paid $€ 1$ bn to be relieved from the obligation to make what would presumably have been a zero net present value (NPV) investment, the purchase at fair value of the $80 \%$ of Fiat Auto that GM did not already own? In our view, GM's wealth constraints were the prime motivation for GM's decision. GM wished to maintain its credit rating, and such rating surely would have been put under pressure by GM's acquisition of a firm that had lost $€ 8$ bn over the period 2001 to 2004, and likely was expected to suffer further losses before returning to profitability.

We acknowledge the preceding limitations, but believe the need for shareholder agreements remains despite these limitations. Although the clauses in the agreements are unlikely entirely to preclude ex post bargaining, they may constrain such bargaining so as to limit the changes in the parties' shares of the payoff, in turn limiting the distortions in the parties' ex ante investments.

\section{Conclusion}

We have presented an explanation for a number of key clauses that often appear in shareholder agreements, such as those between partners in a joint venture and between a venture capitalist and an entrepreneur. The clauses preserve the parties' incentives to make ex ante investments when ex post renegotiation may alter the parties' shares of the payoff.

Many of the clauses we have discussed recall the rules and regulations that govern tender offers and the sale of control blocks. ${ }^{38}$ For example, tag-along rights recall the mandatory bid rule, which requires a bidder to bid for all the shares of a target, and the equal opportunity rule, which requires the acquiror of a control block to offer non-controlling shareholders the same terms and conditions as offered the selling blockholder. Similarly, drag-along rights recall squeezeouts, which allow the acquiror of a control block to squeeze minority shareholders out of the firm.

38. See for example Bebchuk (1994), Bebchuk and Kahan (1999), Burkart, Gromb, and Panunzi (1997, 1998, 2000), Easterbrook and Fischel (1991), Hermalin and Schwartz (1996), Kahan (1993), and Romano (1992). 
Yet there are differences. The offer made to target shareholders in a tender offer may take the form of a two-tier offer, and the market rule rather than the equal opportunity rule governs the sale of control blocks in many jurisdictions, including the United States. In contrast to the equal opportunity rule, the market rule does not impose on the acquiror of a control block the requirement to extend his offer to non-controlling shareholders. Finally, the price at which minority shareholders are squeezed need satisfy only an appraisal standard, which does not entitle minority shareholders to the premium offered the selling blockholder.

Why the differences? In the case of a tender offer, the answer lies in the need to ensure the acquisition is not precluded by the free rider problem (Grossman and Hart 1980). But there should be no such problem in the case of the sale of a control block. In that case, our analysis suggests that the differences are related to the need to induce ex ante investment. Only a controlling blockholder makes such investment. Small, dispersed shareholders do not, as they play no role in management. They therefore make no investment beyond the price of their shares. That only the controlling blockholder makes an ex ante investment, for example in bringing forth a value-creating change of control transaction, suggests that only the controlling blockholder should profit from such a transaction. This is in order to maintain his incentives to make the requisite investment. The appraisal remedy, which effectively grants small shareholders the right to put their shares to the firm, ensures that small shareholders are not harmed by change of control transactions, but also denies them the benefit of these transactions. The need to induce ex ante investment by the controlling blockholder, and by him only, suggests that this is as it should be.

\section{Appendix: An Overview of Shareholder Agreements}

Standard shareholder agreements typically contain the following articles or groups of articles (Bernstein 1988; Freedman 1994; Martel 1991; Stedman and Jones 1990)

Prior agreements. Termination of prior agreements between some or all shareholders regarding the organization and affairs of the company, as well as warranties and covenants specifying that all shares are free and clear of all claims.

Provision of control. Designation of the rights and duties of the shareholders in the management of the company, and requirement of prior unanimous consent for major decisions such as the declaration of any dividend and the issuance or sale of shares.

Restrictions on the transfer of shares. The shareholders commit not to sell, pledge, or charge their shares except with the prior written consent of all other shareholders. 
Survivorship arrangements. Upon the death of any shareholder, the personal representatives of the deceased shall sell the shares of the deceased to the company, typically at a price specified in the article on valuation. Life insurance policies will be issued to the benefit of the shareholders to ensure that this article can be enforced.

Valuation. The fair value of the shares is generally determined by an external expert, or it is based on a previously agreed upon valuation formula.

Right of first refusal. A shareholder offered to sell his shares to an outside investor at some price is required to offer his shares to the other shareholders at the same price. If the other shareholders decline, the first shareholder is free to sell his shares to the outside investor.

Pre-emption rights. A shareholder wishing to sell his stake in the company is required to offer his shares to the other shareholders, typically at "fair value." These are usually substitutes for, and less common than, rights of first refusal.

Put options. A shareholder is granted the option to sell his shares to other shareholders. The strike price is generally the "fair" value of the shares.

Call options. A shareholder is granted the option to buy the shares of other shareholders. The strike price is generally the "fair" value of the shares.

Catch-up clauses. When a shareholder exercises a call option, the selling shareholder maintains a claim on part of the payoff subsequently realized by the first shareholder in a trade sale or an IPO.

Drag-along rights. In case a shareholder sells his stake to an outside investor, drag-along rights grant the shareholder the right to force other shareholders to sell their stakes to the outside investor at the same price and on the same terms as the first shareholders' stake. Drag-along rights can be viewed as conditional call options granted the shareholder.

Tag-along rights (or co-sale agreements). In case a shareholder sells his stake to an outside investor, tag-along rights grant the other shareholders the right to require the outside investor to buy these shareholders' stakes at the same price and on the same terms as the first shareholder's stake. Tag-along rights can be viewed as conditional put options granted shareholders.

Demand rights (or initial public offering clauses). Shareholders agree in advance the circumstances in which they will take the company public. Demand rights ensure that the company will be taken public once a prespecified level of profit is achieved, or when the company has a specific need for outside finance. Demand rights may require all shareholders to participate in the offering.

Piggyback rights. Piggyback rights allow the shareholders to demand to be included in an IPO in proportion to their stakes in the firm.

Non-competition. Each and every shareholder undertakes not to compete with the firm. 
Dispute resolution and arbitration. The shareholders agree to follow a specified procedure to resolve disputes. The procedure may specify the appointment of an arbitrator.

\section{References}

Aghion, Philippe, Patrick Bolton, and Jean Tirole (2004). "Exit Options in Corporate Finance: Liquidity versus Incentives." Review of Finance, 8, 327-353.

Allen, Jeffrey W., and Gordon M. Phillips (2000). "Corporate Equity Ownership, Strategic Alliances, and Product Market Relationships." Journal of Finance, 55, 2791-2815.

Bartlett, Joseph W. (1994). Venture Capital: Law, Business Strategies and Investment Planning. Wiley.

Bebchuk, Lucian A. (1994). "Efficient and Inefficient Sales of Corporate Control." Quarterly Journal of Economics, 109, 957-993.

Bebchuk, Lucian A., and Marcel Kahan (1999). "The "Lemons Effect" in Corporate FreezeOuts." NBER Working Paper No. 6938.

Berglöf, Erik (1994). "A Control Theory of Venture Capital Finance." Journal of Law, Economics, and Organization, 10, 247-267.

Bernstein, Jack (1988). Shareholder Agreements: A Tax and Legal Guide. CCH Canadian Limited.

Bhattacharyya, Suagato, and Francine Lafontaine (1995). "Double-Sided Moral Hazard and the Nature of Share Contracts." Rand Journal of Economics, 26, 761-781.

Bolton, Patrick, and Mathias Dewatripont (2005). Contract Theory. MIT Press.

Burkart, Mike, Denis Gromb, and Fausto Panunzi (1997). "Large shareholders, Monitoring, and the Value of the Firm." Quarterly Journal of Economics, 112, 693-728.

Burkart, Mike, Denis Gromb, and Fausto Panunzi (1998). "Why Higher Takeover Premia Protect Minority Shareholders." Journal of Political Economy, 106, 172-204.

Burkart, Mike, Denis Gromb, and Fausto Panunzi (2000). "Agency Conflicts in Public and Negotiated Transfers of Corporate Control." Journal of Finance, 55, 647-677.

Che, Yeon-Koo, and Donald B. Hausch (1999). "Cooperative Investments and the Value of Contracting." American Economic Review, 89, 125-147.

Cornelli, Francesca, and Oved Yosha (2003). "Stage Financing and the Role of Convertible Securities." Review of Economic Studies, 70, 1-32.

Darrough, Masako N., and Neil M. Stoughton (1989). "A Bargaining Approach to Profit Sharing in Joint Ventures.” Journal of Business, 62, 237-270.

Dessein, Wouter (2005). "Information and Control in Ventures and Alliances." Journal of Finance, 60, 2513-2549.

Doz, Yves L., and Gary Hamel (1998). Alliance Advantage: The Art of Creating Value through Partnering. Harvard Business School Press.

Easterbrook, Frank H., and Daniel R. Fischel (1991). The Economic Structure of Corporate Law. Harvard University Press.

Freedman, Stanley (1994). The Shareholder Agreement: Unprecedented Challenges. Law Society of Upper Canada.

Gompers, Paul A. (1995). "Optimal Investment, Monitoring, and the Staging of Venture Capital." Journal of Finance, 50, 1461-1490.

Grossman, Sanford J., and Oliver D. Hart (1980). "Takeovers Bids, the Free-Rider Problem, and the Theory of the Corporation." Bell Journal of Economics, 11, 42-64.

Grossman, Sanford J., and Oliver D. Hart (1986). "The Costs and Benefits of Ownership: A Theory of Vertical and Lateral Integration.” Journal of Political Economy, 94, 691-719.

Hart, Oliver (1995). Firms, Contracts, and Financial Structure. Oxford University Press. 
Hart, Oliver and John Moore (1988). "Incomplete Contracts and Renegotiation.” Econometrica, $56,755-785$.

Hart, Oliver, and John Moore (1990). "Property Rights and the Nature of the Firm." Journal of Political Economy, 98, 1119-1158.

Hauswald, Robert, and Ulrich Hege (2004). "Ownership and Control in Joint Ventures: Theory and Evidence." Working paper, University of Maryland and HEC Paris.

Hellmann, Thomas (1998). "The Allocation of Control Rights in Venture Capital Contracts." Rand Journal of Economics, 29, 57-76.

Hellmann, Thomas (2001). "IPOs, Acquisitions, and the Use of Convertible Securities in Venture Capital.” Working paper, Stanford University.

Hermalin, Benjamin, and Alan Schwartz (1996). "Buyouts in Large Companies." Journal of Legal Studies, 25, 351-370.

Herzfeld, Edgar, and Adam Wilson (1996). Joint Ventures. Jordans.

Holmström, Bengt (1982). "Moral Hazard in Teams." Bell Journal of Economics, 13, 324-340.

Inderst, Roman, and Holger M. Müller (2004). "The Effect of Capital Market Characteristics on the Value of Start-up Firms." Journal of Financial Economics, 72, 319-356.

Johnson, Simon, Rafael La Porta, Florencio Lopez de Silanes, and Andrei Shleifer (2000). “Tunneling." American Economic Review, 90, 22-27.

Kahan, Marcel (1993). "Sales of Corporate Control." Journal of Law, Economics, and Organization, 9, 368-379.

Kahan, Marcel (2000). "An Economic Analysis of Rights of First Refusal.” Working paper, New York University School of Law.

Kaplan, Steven N., and Per Strömberg (2003). "Financial Contracting Theory Meets the Real World: An Empirical Analysis of Venture Capital Contracts." Review of Economic Studies, 70, 281-315.

Kaplan, Steven N., and Per Strömberg (2004). "Characteristics, Contracts, and Actions: Evidence from Venture Capital Analyses.” Journal of Finance, 59, 2170-2210.

Kirilenko, Andrei (2001). "Valuation and Control in Venture Finance." Journal of Finance, 56, 565-587.

Legros, Patrick, and Steven A. Matthews (1993). "Efficient and Nearly-Efficient Partnerships." Review of Economic Studies, 60, 599-611.

Lerner, Josh, and Antoinette Schoar (2003). "Private Equity in the Developing World: The Determinants of Transaction Structures.” Working paper, Harvard University and MIT.

Martel, Paul (1991). Les Conventions entre Actionnaires. Wilson and Lafleur.

Maskin, Eric, and Jean Tirole (1999). "Unforeseen Contingencies and Incomplete Contracts." Review of Economic Studies, 66, 83-114.

McConnell, John J., and Timothy J. Nantell (1985). "Corporate Combinations and Common Stock Returns: The Case of Joint Ventures.” Journal of Finance, 40, 519-536.

Mohanram, Partha, and Ashish Nanda (1998). "When do Joint Ventures Create Value?" Working paper, Harvard Business School.

Neher, Darwin V. (1999). "Staged Financing: An Agency Perspective.” Review of Economic Studies, 66, 255-274.

Nöldeke, Georg, and Klaus M. Schmidt (1995). "Option Contracts and Renegotiation: A Solution to the Hold-Up Problem." Rand Journal of Economics, 26, 163-79.

Nöldeke, Georg, and Klaus M. Schmidt (1998). "Sequential Investments and Options to Own." Rand Journal of Economics, 29, 633-653.

Oxley, Joanne E. (1997). "Appropriability Hazards and Governance in Strategic Alliances: A Transaction Cost Approach." Journal of Law, Economics, and Organization, 13, 387-409.

Pisano, Gary (1989). "Using Equity Participation to Support Exchange: Evidence from the Biotechnology Industry.” Journal of Law, Economics, and Organization, 5, 109-126.

Reich, Robert B., and Eric D. Mankin (1986). "Joint Ventures with Japan Give Away Our Future." Harvard Business Review, 78-86. 
Repullo, Rafael, and Javier Suarez (1998). "Monitoring, Liquidation, and Security Design.” Review of Financial Studies, 11, 163-187.

Rey, Patrick, and Jean Tirole (1998). "Divergence of Objectives and the Governance of Joint Ventures." Working paper, IDEI.

Robinson, David T., and Toby E. Stuart (2002). "Financial Contracting in Biotech Strategic Alliances." Working paper, University of Chicago.

Romano, Roberta (1992). "A Guide to Takeovers: Theory, Evidence, and Regulation." Yale Journal of Regulation, 9, 119-180.

Schmidt, Klaus (2003). "Convertible Securities and Venture Capital Finance." Journal of Finance, 58, 1139-1166.

Scott, Graham (1999). Mining: Drafting Joint Venture Agreements. The Continuing Legal Education Society of British Columbia.

Stedman, Graham, and Janet Jones (1990). Shareholders' Agreements, 2nd ed. Longman.

Williamson, Oliver E. (1985). The Economic Institutions of Capitalism: Firms, Markets, Relational Contracting. Free Press. 